\title{
Pengaruh Perilaku Keluarga Sadar Gizi (Kadarzi) terhadap Status Gizi Balita
}

\author{
Rodiah $^{1}$, Nining Arini ${ }^{2}$, Abdullah Syafei ${ }^{3}$ \\ ${ }^{1}$ Puskesmas Bogor Utara Jalan R. Kan'an No.81 Kota Bogor Telp (0251) 8363644 \\ 2,3Program Sarjana Ilmu Kesehatan Masyarakat, Sekolah Tinggi Ilmu Kesehatan Indonesia Maju \\ Gedung HZ Jalan Harapan No,50 Lenteng Agung Jakarta Selatan Kode Pos 1260 Telp (021) 788940444/45 \\ Email: ${ }^{1}$ diahsofyan11@gmail.com, ${ }^{2}$ nining.arini@gmail.com
}

\begin{abstract}
Abstrak
Keluarga sadar Gizi (Kadarzi) adalah keluarga yang mempraktekkan perilaku gizi dengan baik dan benar. Kadarzi dapat mengenali dan mengatasi masalah gizi dalam keluarga atau lingkungan. Balita merupakan kelompok umur yang rentan terhadap masalah gizi. Kesadaran keluarga dalam pemeliharaan gizi Balita sangat memengaruhi status gizi Balita. Penelitian ini bertujuan menganalisis pengaruh perilaku Keluarga Sadar Gizi (Kadarzi) terhadap status gizi Balita di Kelurahan Cimahpar Kota Bogor Tahun 2016. Penelitian ini menggunakan metode survei cross sectional, populasinya adalah keluarga yang tinggal di Kelurahan Cimahpar yang mempunyai anak Balita usia 6-59 bulan. Perhitungan sampel menggunakan metode Slovin dan diperoleh 400 sampel. Pengambilan sampel dipilih secara purposive sampling. Jenis data yang dikumpulkan adalah data sekunder hasil survei Kadarzi dan kegiatan Bulan Penimbangan Balita (BPB) Puskesmas Bogor Utara tahun 2016. Analisis data dalam penelitian ini berupa analisis univariat, bivariat, dan multivariat. Hasil uji chi square menunjukkan ada hubungan yang signifikan antara lima indikator Kadarzi dan perilaku Kadarzi dengan status gizi Balita. Hasil uji korelasi spearman menunjukkan lima indikator Kadarzi dan perilaku Kadarzi mempunyai korelasi positif terhadap status gizi Balita. Indikator konsumsi makan beragam mempunyai nilai korelasi paling tinggi terhadap status gizi Balita menurut indeks Berat Badan terhadap Umur (BB/U). Indikator pemberian ASI eksklusif mempunyai nilai korelasi paling tinggi terhadap status gizi Balita menurut indeks Tinggi Badan terhadap Umur (TB/U). Saran pada penelitian ini adalah meningkatkan motivasi ibu memberikan ASI eksklusif dengan memberikan hadiah dan sertifikat bagi bayi yang lulus ASI eksklusif sampai usia 6 bulan.
\end{abstract}

Kata kunci : Balita, Keluarga Sadar Gizi (Kadarzi), Perilaku, Status Gizi

\begin{abstract}
Nutrition conscious family (Kadarzi) is a family who practice well and correctly nutritional behavior. Kadarzi can recognize and resolve nutritional problem in the family or social environment. Toddlers are the age group that susceptible to nutritional problem. Conscious familly in awareness nutritional greatly affect to toddler nutritional status. This research aimed to analyze influence of Kadarzi nutrition behavior toward toddler nutritional status at Cimahpar village Bogor City in 2016. This research used cross sectional survey method which population are families at Cimahpar village who have 6-59 months old toddler. About 400 samples were analyzed by Slovin method. Samples were selected by purposive sampling. The kind of data retrieved were secondary data resulted from Kadarzi survey and monthly toddler weighting activity in 2016. Data analyzed in this research were univariate, bivariate, and multivariate analysis. Chi square test result showed there were relation significantly between five Kadarzi indicators and Kadarzi behavior toward toddler nutritional status. Spearman correlation test result showsed five Kadarzi indicators and Kadarzi behavior had correlation toward toddler nutritional status positively. the consumption of diverse foods indicator had the highest correlation value toward toddler nutritional status with Berat Badan terhadap Umur (BB/U) index. The indicator of exclusive breastfeeding had the highest correlation value toward toddler nutritional status with Tinggi Badan terhadap Umur (TB/U) index.

Keywords : Toddler, Conscious Family (Kadarzi), Behavior, Nutritional Status
\end{abstract}




\section{Pendahuluan}

Keluarga Sadar Gizi (Kadarzi) adalah keluarga yang mempraktekkan perilaku gizi yang baik dan benar. Kadarzi dapat mengenali dan mengatasi masalah gizi yang ada dalam keluarga dan lingkungan. Berdasarkan Keputusan Menteri Kesehatan Republik Indonesia (Kepmenkes RI) nomor: 747/Menkes/SK/2007 dijabarkan bahwa pengertian Kadarzi sebagai suatu keluarga yang mampu mengenal, mencegah, dan mengatasi masalah gizi setiap anggotanya. Tujuan umum program Kadarzi adalah seluruh keluarga berperilaku sadar gizi. Tujuan khusus Kadarzi adalah meningkatkan kemudahan keluarga dan masyarakat untuk memperoleh informasi gizi dan pelayanan gizi yang berkualitas. Perilaku Kadarzi memiliki 5 indikator yaitu: (1) menimbang berat badan secara teratur; (2) memberikan ASI eksklusif; (3) konsumsi makanan beragam; menggunakan garam beryodium, dan (5) Konsumsi suplemen gizi sesuai anjuran. ${ }^{1}$

Kebijakan dan strategi pembangunan kesehatan nasional tahun 2015-2019 bertujuan untuk meningkatkan kesadaran, kemauan, dan kemampuan hidup sehat bagi setiap orang. Adapun tujuan akhir rencana tersebut adalah meningkatkan derajat kesehatan masyarakat yang setinggi-tingginya. Tujuan tersebut tercapai jika penduduknya berperilaku sehat dan dalam lingkungan yang sehat. Selain itu penduduk memiliki kemampuan untuk menjangkau pelayanan kesehatan yang bermutu secara adil dan merata. Peningkatan derajat kesehatan masyarakat ditunjukkan oleh meningkatnya Umur Harapan Hidup (UHH). Selain itu juga menurunnya Angka Kematian Bayi (AKB), menurunnya Angka Kematian Ibu (AKI), dan menurunnya prevalensi gizi kurang pada Balita. $^{2}$

Permasalahan gizi di Indonesia saat ini semakin kompleks. Masalah yang dihadapi antara lain kekurangan gizi dan kelebihan gizi yang harus ditangani dengan serius. Rencana Pembangunan Jangka
Menengah Nasional (RPJMN) Kemenkes 2015-2019 menyebutkan bahwa perbaikan status gizi masyarakat merupakan salah satu prioritas utama. Upaya yang dilakukan adalah menurunkan prevalensi Balita berstatus gizi kurang (underweight) dari $19,6 \%$ pada tahun 2013 menjadi $17 \%$ pada tahun 2019. Selain itu menurunkan prevalensi Balita berstatus pendek (stunting) dari 32,9\% menjadi 28\%. Hasil Riset Kesehatan Dasar (Riskesdas) Kemenkes 2007-2013 menunjukkan fakta bahwa underweight meningkat dari 18,4\% menjadi $19,6 \%$. Stunting juga meningkat dari $36,8 \%$ menjadi $37,2 \%$, sementara Balita kurus (wasting) menurun dari 13,6\% menjadi 12,1\%. Riskesdas Kemenkes 2010 dan 2013 menunjukkan bahwa kelahiran bayi dengan Berat Badan Lahir Rendah (BBLR) $<2.500$ gram menurun dari $11,1 \%$ menjadi $10,2 \%{ }^{3}$

Dinas Kesehatan (Dinkes) Kota Bogor mengelompokkan kasus gizi di Kota Bogor berdasarkan indikator $\mathrm{BB} / \mathrm{U}$ dan $\mathrm{TB} / \mathrm{U}$. Berdasarkan indikator $\mathrm{BB} / \mathrm{U}$ Kelompok berstatus gizi kurang tahun 2015 sebesar 5,44\%. Angka tersebut cenderung meningkat dibandingkan dengan tahun 2014 yaitu 5,16\%. Kasus gizi berdasarkan indikator BB/TB tahun 2015 terdapat 2,48\% Balita berstatus gizi kurus dan kurus sekali. Data tersebut sama dengan data tahun 2014. Kasus stunting pada tahun 2014 sebesar $16,7 \%$ dan meningkat pada tahun 2015 menjadi $19,7 \%{ }^{4}$

Puskesmas Bogor Utara melakukan kegiatan Bulan penimbangan Balita (BPB) Puskesmas Bogor Utara pada bulan Agustus 2015. Hasil kegiatan tersebut menunjukkan terdapat beberapa kasus gizi. Berdasarkan indikator $\mathrm{BB} / \mathrm{U}$ terdapat kasus gizi buruk sebesar $0,85 \%$ dan gizi kurang $3,85 \%$. Berdasarkan indikator TB/U terdapat kasus stunting sebesar 19,69\%. Berdasarkan indikator $\mathrm{BB} / \mathrm{TB}$ terdapat $1,03 \%$ Balita berstatus gizi kurus dan kurus sekali. Kelurahan Cimahpar merupakan salah satu wilayah binaan Puskesmas Bogor Utara. Berdasarkan indikator BB/U, 
terdapat kasus gizi buruk sebesar $1 \%$ dan gizi kurang 4,2\%. Berdasarkan indikator TB/U menunjukkan kasus stunting sebesar $21,9 \%$ dan berdasarkan indikator $\mathrm{BB} / \mathrm{TB}$ terdapat 1,3\% Balita kurus dan kurus sekali. $^{5}$

Perbaikan gizi pada program Kementerian Kesehatan Indonesia tahun 2015 lebih ditekankan pada peningkatan status gizi melalui perilaku sehat. Upaya tersebut dilakukan melalui pemberdayaan petugas kesehatan, masyarakat dan keluarga. Salah satu strategi meningkatkan pemberdayaan keluarga adalah melalui upaya mewujudkan Keluarga Sadar Gizi (Kadarzi). Kadarzi merupakan salah satu langkah strategis untuk menangani masalah gizi. Permasalahan tersebut muncul akibat pendidikan, perilaku, dan lingkungan keluarga yang tidak mendukung. ${ }^{2}$

Puskesmas Bogor Utara telah melakukan pemetaan Kadarzi pada tahun 2013-2015. Diketahui pada tahun 2013 terdapat $87,1 \%$ dari 9349 keluarga yang tergolong Kadarzi. Namun pada tahun 2014 persentasenya menurun menjadi $86,20 \%$, lalu pada tahun 2015 naik menjadi 93,41\%. Data pemetaan Kadarzi Kelurahan Cimahpar menunjukkan bahwa pada tahun 2013 terdapat 84,4\% dari 2987 keluarga yang tergolong Kadarzi. Data tersebut meningkat pada tahun 2014 menjadi 88\%, juga pada tahun 2015 menjadi 91,1\%. ${ }^{5}$

Data survei Kadarzi Kelurahan Cimahpar tahun 2015 menunjukkan pencapaian lima indikator Kadarzi. Pencapaian tersebut adalah sebagai berikut: (1) menimbang berat badan secara teratur sebanyak $82,4 \%$; (2) memberikan ASI eksklusif sebanyak 30,8\%; (3) konsumsi makanan beragam sebanyak $80,1 \%$; (4) menggunakan garam beryodium sebanyak $97,2 \%$ dan (5) konsumsi suplemen gizi sesuai anjuran sebanyak $94,8 \%{ }^{5}$

Mengubah perilaku keluarga menjadi keluarga sadar gizi bukanlah hal yang mudah. Upaya tersebut dapat dilakukan dengan memberikan pendidikan gizi kepada masyarakat secara terus-menerus. Upaya lainnya yaitu menyebarluaskan informasi melalui media massa serta membina dan menggerakkan tokoh juga kelompok-kelompok masyarakat. Selain itu juga memberikan pendampingan kepada keluarga baik oleh tenaga profesional maupun masyarakat terlatih. Guna melihat keterkaitan perilaku Kadarzi dengan status gizi Balita, maka diperlukan analisis hubungan perilaku Keluarga Sadar Gizi (Kadarzi) dengan status gizi Balita.

\section{Metode}

Penelitian ini menggunakan metode survei cross sectional dengan mengolah dan menganalisis data sekunder. Data yang digunakan adalah data hasil kegiatan Bulan Penimbangan Balita (BPB) dan hasil survei Kadarzi Puskesmas Bogor Utara tahun 2016. Berdasarkan data tersebut kemudian dipilih secara purposive sampling sebanyak 400 sampel keluarga di Kelurahan Cimahpar yang memiliki Balita usia 6-59 bulan yang memiliki data Kadarzi dan antropomteri yang lengkap.

Survei Kadarzi dan kegiatan BPB dilaksanakan oleh kader Posyandu. Kader Posyandu melakukan pengukuran antropometri, wawancara dan uji iodium. Pengukuran antropometri digunakan untuk mengetahui status gizi Balita menggunakan indeks Berat Badan menurut Umur (BB/U) dan Tinggi Badan menurut Umur $(\mathrm{TB} / \mathrm{U})$. Pengukuran tersebut diinterprestasikan berdasarkan standar World Health Organization (WHO). Data perilaku Kadarzi diperoleh dengan menggunakan kuesioner sebagai pedoman wawancara. Kuesioner tersebut digunakan untuk memperoleh data penimbangan berat badan Balita, pemberian ASI eksklusif, konsumsi makanan beragam, dan konsumsi suplemen gizi pada Balita. Kandungan iodium garam yang digunakan oleh keluarga diperoleh dengan pengujian kandungan iodium menggunakan uji iodina. Uji iodina dilakukan dengan cara meneteskan cairan uji iodina kedalam garam. Hasil uji dilihat berdasarkan 
perubahan warna. Apabila garam berubah warna menjadi ungu berarti garam tersebut mengandung iodium. ${ }^{1}$

Data yang dikumpulkan kemudian diolah menggunakan program perhitungan komputerisasi Statistical Package for the Social Sciens (SPSS) versi 22.0 for window. Analisis data menggunakan uji chi square dengan tingkat kepercayaan 95\% dan uji korelasi spearman.

Analisis data dalam penelitian ini berupa analisis univariat, bivariat dan multivariat. Penyajian data ditampilkan dalam bentuk tabel searah dan tabel silang.

\section{Hasil}

\section{Karakteristik Responden}

Hasil penelitian menunjukkan bahwa jumlah Balita berjenis kelamin perempuan lebih banyak dibandingkan dibandingkan dengan Balita berjenis kelamin laki-laki (berturut-turut 207 dan 193 orang). Usia Balita terbanyak 24-59 bulan (66,5\%), terendah usia 6-12 bulan (9,0\%). Kategori status ekonomi ditentukan berdasarkan kepemilikan kartu jaminan kesehatan. Keluarga yang memiliki kartu jaminan kesehatan Penerima Bantuan Iuran (PBI) dikategorikan menjadi keluarga miskin dan keluarga yang memiliki kartu jaminan kesehatan non PBI atau belum memiliki kartu jaminan kesehatan dikategorikan non keluarga miskin. Persentase keluarga miskin $(21,2 \%)$ dan non keluarga miskin $(78,8 \%)$ Karakteristik responden dijelaskan pada tabel 1.

Hasil penelitian menunjukkan pencapaian lima indikator Kadarzi dengan kategori belum baik dan baik. Responden yang sudah melakukan penimbangan berat badan secara teratur sebanyak 88,8\%. Keluarga yang memberikan ASI eksklusif pada bayi 0-6 bulan sebanyak $61,8 \%$. Keluarga yang mampu memberikan makanan beragam sebanyak 80,3\%. Responden yang sudah menggunakan garam beryodium sebanyak 97,3\%. Responden yang sudah mengonsumsi suplemen gizi sesuai anjuran sebanyak 95,7\%. Responden yang sudah Kadarzi lebih banyak daripada yang belum Kadarzi (berturut-turut 53,8\% dan 46,2\%.

Tabel 1. Karakteristik responden berdasarkan jenis kelamin Balita, usia Balita dan status ekonomi keluarga.

\begin{tabular}{lrr}
\hline Karakteristik & $\begin{array}{c}\text { Jumlah } \\
(\mathbf{n})\end{array}$ & $\begin{array}{r}\text { Persentase } \\
(\%)\end{array}$ \\
\hline Jenis Kelamin Balita & & \\
Laki-laki & 193 & 48,2 \\
Perempuan & 207 & 51,8 \\
Usia Balita (bulan) & & \\
6-11 & 36 & 9,0 \\
12-23 & 98 & 24,5 \\
24-59 & 328 & 66,5 \\
Status ekonomi keluarga & & \\
Keluarga miskin & 85 & 21,2 \\
Non keluarga miskin & 315 & 78,8 \\
\hline
\end{tabular}

Gambaran responden berdasarkan lima indikator Kadarzi dan perilaku Kadarzi dijelaskan pada Tabel 2.

Tabel 2. Persentase pencapaian lima indikator Kadarzi dan perilaku Kadarzi Kelurahan Cimahpar tahun 2016

\begin{tabular}{|c|c|c|c|c|}
\hline \multirow{2}{*}{$\begin{array}{l}\text { Indikator } \\
\text { Kadarzi }\end{array}$} & \multicolumn{2}{|c|}{$\begin{array}{c}\text { Belum } \\
\text { baik }\end{array}$} & \multicolumn{2}{|c|}{ Baik } \\
\hline & $\mathrm{n}$ & $\%$ & $\mathrm{n}$ & $\%$ \\
\hline $\begin{array}{l}\text { Menimbang } \\
\text { berat badan } \\
\text { secara teratur } \\
\text { Memberi }\end{array}$ & 45 & 11,2 & 355 & 88,8 \\
\hline $\begin{array}{l}\text { kan ASI } \\
\text { eksklusif }\end{array}$ & 153 & 38,2 & 247 & 61,8 \\
\hline $\begin{array}{l}\text { Konsumsi } \\
\text { makanan } \\
\text { beragam }\end{array}$ & 79 & 19,7 & 321 & 80,3 \\
\hline $\begin{array}{l}\text { Menggunakan } \\
\text { garam } \\
\text { beryodium }\end{array}$ & 11 & 2,7 & 389 & 97,3 \\
\hline $\begin{array}{l}\text { Konsumsi } \\
\text { suplemen gizi }\end{array}$ & 17 & 4,3 & 383 & 95,7 \\
\hline $\begin{array}{l}\text { Perilaku } \\
\text { Kadarzi }\end{array}$ & 185 & 46,2 & 215 & 53,8 \\
\hline
\end{tabular}

\section{Gambaran Status Gizi Balita}

Hasil penelitian menunjukkan bahwa berdasarkan indeks BB/U sebagian besar Balita mempunyai status gizi baik yaitu 326 orang $(81,5 \%)$, status gizi buruk sebanyak 16 orang (4\%), status gizi kurang sebanyak 50 orang $(12,5 \%)$ dan status gizi lebih sebanyak 8 orang $(2,0 \%)$. Berdasarkan indeks TB/U sebagian besar Balita mempunyai status gizi normal yaitu 
308 orang $(77,0 \%)$. Masih ditemukan Balita sangat pendek sebanyak 23 orang $(5,8 \%)$ dan Balita pendek sebanyak 66 orang $(16,5 \%)$. Gambaran status gizi Balita dijelaskan pada Tabel 3.

Tabel 3. Persentase status gizi Balita di Kelurahan Cimahpar tahun 2016

\begin{tabular}{lcc}
\hline \multicolumn{1}{c}{ Status Gizi Balita } & $\begin{array}{c}\text { Jumlah } \\
(\mathbf{n})\end{array}$ & $\begin{array}{c}\text { Persentase } \\
(\%)\end{array}$ \\
\hline Berat badan menurut & & \\
umur (BB/U) & & \\
$\quad$ Buruk & 16 & 4,0 \\
Kurang & 50 & 12,5 \\
Baik & 326 & 81,5 \\
$\quad$ Lebih & 8 & 2,0 \\
Tinggi badan & & \\
menurut umur & & \\
(TB/U) & & \\
$\quad$ Sangat pendek & 23 & 5,8 \\
$\quad$ Pendek & 66 & 16,5 \\
Normal & 308 & 77,0 \\
Tinggi & 3 & 0,8 \\
\hline
\end{tabular}

Gambaran Status Gizi Balita Menurut Indeks $\mathrm{BB} / \mathrm{U}$ berdasarkan Lima Indikator Kadarzi dan Perilaku Kadarzi Gambaran status gizi Balita menurut indeks $\mathrm{BB} / \mathrm{U}$ berdasarkan lima indikator Kadarzi dan perilaku Kadarzi dijelaskan pada Tabel 4. Keluarga yang mengonsumsi makanan beragam memiliki Balita berstatus gizi baik lebih banyak dibandingkan dengan keluarga yang belum mengonsumsi makanan beragam (berturut-turut 299 dan 27 orang). Keluarga yang menggunakan garam beryodium memiliki Balita dengan status gizi baik sebanyak 323 orang, sedangkan pada keluarga yang belum menggunakan garam beryodium memiliki Balita dengan status gizi baik hanya 3 orang.

Tabel 4. Persentase status gizi Balita menurut indeks BB/U berdasarkan lima indikator Kadarzi

\begin{tabular}{|c|c|c|c|c|c|c|c|c|c|c|c|c|}
\hline \multirow{3}{*}{$\begin{array}{c}\text { Indikator } \\
\text { Kadarzi }\end{array}$} & \multicolumn{8}{|c|}{ Status Gizi (BB/U) } & \multicolumn{2}{|c|}{ Jumlah } & \multicolumn{2}{|c|}{ Uji Statistik } \\
\hline & \multicolumn{2}{|c|}{ Buruk } & \multicolumn{2}{|c|}{ Kurang } & \multicolumn{2}{|c|}{ Baik } & \multicolumn{2}{|c|}{ Lebih } & \multirow[t]{2}{*}{$\mathbf{n}$} & \multirow[t]{2}{*}{$\%$} & \multirow{2}{*}{$\begin{array}{c}\text { Nilai } \\
\mathbf{P}\end{array}$} & \multirow{2}{*}{$\begin{array}{c}\text { Nilai } \\
\text { Korelasi }\end{array}$} \\
\hline & $\mathbf{n}$ & $\%$ & $\mathbf{n}$ & $\%$ & $\mathbf{n}$ & $\%$ & $\mathrm{n}$ & $\%$ & & & & \\
\hline \multicolumn{13}{|l|}{$\begin{array}{l}\text { Menimbang } \\
\text { berat badan }\end{array}$} \\
\hline Belum baik & 9 & 2,3 & 9 & 2,3 & 27 & 6,6 & 0 & 0,0 & 45 & 11,2 & 0,000 & 0,241 \\
\hline Baik & 7 & 1,7 & 41 & 10,2 & 299 & 74,9 & 8 & 2,0 & 355 & 88,8 & & \\
\hline \multicolumn{13}{|l|}{ Memberikan } \\
\hline \multicolumn{13}{|l|}{ Eksklsusif } \\
\hline Belum baik & 13 & 3,3 & 38 & 9,5 & 100 & 24,9 & 2 & 0,5 & 153 & 38,2 & 0,000 & 0,346 \\
\hline Baik & 3 & 0,7 & 12 & 3,0 & 226 & 56,6 & 6 & 1,5 & 247 & 61,8 & & \\
\hline \multicolumn{13}{|l|}{$\begin{array}{l}\text { Konsumsi } \\
\text { makanan } \\
\text { beragam }\end{array}$} \\
\hline Belum baik & 11 & 2,8 & 34 & 8,5 & 27 & 6,8 & 7 & 1,8 & 79 & 19,7 & 0,000 & 0,432 \\
\hline Baik & 5 & 1,2 & 16 & 4,0 & 299 & 74,7 & 1 & 0,2 & 321 & 80,3 & & \\
\hline \multicolumn{13}{|l|}{$\begin{array}{l}\text { Menggunakan } \\
\text { garam } \\
\text { beryodium }\end{array}$} \\
\hline Belum baik & 6 & 1,5 & 2 & 0,5 & 3 & 0,7 & 0 & 0,0 & 11 & 2,7 & 0,000 & 0,271 \\
\hline Baik & 10 & 2,5 & 48 & 12,0 & 323 & 80,8 & 8 & 2,0 & 399 & 97,3 & & \\
\hline \multicolumn{13}{|l|}{$\begin{array}{l}\text { Konsumsi } \\
\text { suplemen gizi } \\
\text { sesuai anjuran }\end{array}$} \\
\hline Belum baik & 4 & 1,0 & 3 & 0,7 & 10 & 2,6 & 0 & 0,0 & 17 & 4,3 & 0,000 & 0,152 \\
\hline Baik & 12 & 3,0 & 47 & 11,8 & 316 & 78,9 & 8 & 2,0 & 383 & 95,7 & & \\
\hline Status Kadarzi & & & & & & & & & & & & \\
\hline $\begin{array}{l}\text { Belum } \\
\text { Kadarzi }\end{array}$ & 15 & 3,8 & 43 & 10,7 & 120 & 29,9 & 7 & 1,8 & 185 & 46,2 & 0,000 & 0,313 \\
\hline $\begin{array}{l}\text { Sudah } \\
\text { Kadarzi }\end{array}$ & 1 & 0,2 & 7 & 1,8 & 206 & 51,6 & 1 & 0,2 & 215 & 53,8 & & \\
\hline
\end{tabular}


Tabel 4 juga menjelaskan bahwa keluarga yang mengonsumsi suplemen gizi sesuai anjuran memiliki Balita dengan status gizi baik sebanyak 316 orang dan pada keluarga yang belum mengonsumsi suplemen gizi sesuai anjuran memiliki Balita dengan status gizi baik sebanyak 10 orang. Keluarga yang sudah berperilaku Kadarzi memiliki Balita dengan status gizi baik lebih banyak yaitu 206 orang dibandingkan dengan keluarga yang belum berperilaku Kadarzi yaitu 120 orang. Balita berstatus gizi buruk dan kurang ditemukan pada keluarga yang belum berperilaku Kadarzi yaitu masingmasing 15 dan 43 orang. Pada keluarga yang sudah berperilaku Kadarzi hanya ditemukan satu orang dengan status gizi buruk dan tujuh orang dengan status gizi kurang. Hasil uji chi square menunjukkan bahwa lima indikator Kadarzi dan perilaku Kadarzi berpengaruh terhadap status gizi Balita berdasarkan indeks BB/U. Nilai probabilitas (p) masing-masing indikator dan perilaku Kadarzi kurang dari 0,05. hal tersebut menunjukkan bahwa semua indikator Kadarzi dan perilaku Kadarzi mempunyai hubungan yang signifikan terhadap status gizi Balita. Untuk menganalisis arah hubungan dan besarnya pengaruh variabel independen terhadap variabel dependen dilakukan uji korelasi spearman. Hasil uji korelasi spearman menunjukkan lima indikator Kadarzi dan perilaku Kadarzi mempunyai nilai korelasi positif terhadap status gizi Balita menurut indeks BB/U. Hal tersebut berarti semakin baik perilaku dari masing-masing indikator Kadarzi dan perilaku Kadarzi, maka semakin baik status gizi Balita menurut indeks BB/U. Hasil analisis menunjukkan nilai korelasi paling tinggi terdapat pada perilaku mengonsumsi makanan beragam yaitu 0,432 . Semakin tinggi nilai korelasi maka pengaruh variabel independen terhadap variabel dependen semakin besar. Hal tersebut berarti bahwa perilaku mengonsumsi makanan beragam mempunyai pengaruh yang paling besar terhadap status gizi Balita menurut indeks $\mathrm{BB} / \mathrm{U}$.

\section{Gambaran Status Gizi Balita Menurut Indeks $\mathrm{TB} / \mathrm{U}$ Berdasarkan Lima Indikator Kadarzi dan Perilaku Kadarzi}

Hasil penelitian menunjukkan bahwa keluarga yang menimbang berat badan secara teratur memiliki Balita dengan tinggi badan normal lebih banyak dibandingkan dengan keluarga yang belum menimbang berat badan secara teratur (berturut-turut 295 dan 13orang). Keluarga yang memberikan ASI eksklusif memiliki Balita dengan tinggi badan normal sebanyak 233 orang, sedangkan pada keluarga yang tidak memberikan ASI eksklusif memiliki Balita dengan tinggi badan normal hanya 75 orang. Keluarga yang mengonsumsi makanan beragam memiliki Balita memiliki Balita dengan tinggi badan normal lebih banyak dibandingkan dengan keluarga yang belum mengonsumsi makanan beragam (berturut-turut 281 dan 27 orang).

Keluarga yang menggunakan garam beryodium memiliki Balita dengan tinggi badan normal sebanyak 308 orang. Keluarga yang belum menggunakan garam beryodium tidak memiliki Balita dengan tinggi badan normal. Keluarga yang mengonsumsi suplemen gizi sesuai anjuran memiliki Balita dengan tinggi badan normal sebanyak 306 orang dan pada keluarga yang belum mengonsumsi suplemen gizi sesuai anjuran memiliki Balita dengan tinggi badan normal sebanyak dua orang.

Keluarga yang sudah berperilaku Kadarzi memiliki Balita dengan tinggi badan normal lebih banyak yaitu 205 orang dibandingkan dengan keluarga yang belum berperilaku Kadarzi yaitu 103 orang. Balita pendek dan sangat pendek ditemukan lebih banyak pada keluarga yang belum berperilaku Kadarzi dibandingkan dengan keluarga yang sudah Kadarzi (berturut-turut 81 dan 8 orang). 
Tabel 5. Persentase status gizi Balita menurut indeks TB/U berdasarkan lima indikator Kadarzi dan perilaku Kadarzi di Kelurahan Cimahpar tahun 2016

\begin{tabular}{|c|c|c|c|c|c|c|c|c|c|c|c|c|}
\hline \multirow{3}{*}{$\begin{array}{c}\text { Indikator } \\
\text { Kadarzi }\end{array}$} & \multicolumn{8}{|c|}{ Status Gizi (TB/U) } & \multicolumn{2}{|c|}{ Jumlah } & \multicolumn{2}{|c|}{ Uji Statistik } \\
\hline & \multicolumn{2}{|c|}{ Buruk } & \multicolumn{2}{|c|}{ Kurang } & \multicolumn{2}{|c|}{ Baik } & \multicolumn{2}{|c|}{ Lebih } & \multirow[t]{2}{*}{$\mathbf{n}$} & \multirow[t]{2}{*}{$\%$} & \multirow{2}{*}{$\begin{array}{c}\text { Nilai } \\
\mathbf{P}\end{array}$} & \multirow{2}{*}{$\begin{array}{c}\text { Nilai } \\
\text { Korelasi }\end{array}$} \\
\hline & $\mathbf{n}$ & $\%$ & $\mathbf{n}$ & $\%$ & $\mathbf{n}$ & $\%$ & $\mathbf{n}$ & $\%$ & & & & \\
\hline $\begin{array}{l}\text { Menimbang } \\
\text { berat badan }\end{array}$ & & & & & & & & & & & & \\
\hline Belum baik & 9 & 2,2 & 23 & 5,7 & 13 & 3,3 & 0 & 0,0 & 45 & 11,2 & 0,000 & 0,415 \\
\hline Baik & 14 & 3,6 & 43 & 10,8 & 295 & 73,7 & 3 & 0,8 & 355 & 88,8 & & \\
\hline $\begin{array}{l}\text { Memberikan } \\
\text { ASI } \\
\text { Eksklsusif }\end{array}$ & & & & & & & & & & & & \\
\hline Belum baik & 21 & 5,2 & 57 & 14,2 & 75 & 18,8 & 0 & 0,0 & 153 & 38,2 & 0,000 & 0,543 \\
\hline Baik & 2 & 0,6 & 9 & 2,3 & 233 & 58,2 & 3 & 0,8 & 247 & 61,8 & & \\
\hline $\begin{array}{l}\text { Konsumsi } \\
\text { makanan } \\
\text { beragam } \\
\text { Belum baik }\end{array}$ & 15 & 3,7 & 36 & 9,0 & 27 & 6,8 & 1 & 0,2 & 79 & 19,7 & 0,000 & 0,493 \\
\hline Baik & 8 & 2,1 & 30 & 7,5 & 281 & 70,2 & 2 & 0,6 & 321 & 80,3 & & \\
\hline $\begin{array}{l}\text { Menggunakan } \\
\text { garam } \\
\text { beryodium }\end{array}$ & & & & & & & & & & & & \\
\hline Belum baik & 7 & 1,7 & 4 & 1,0 & 0 & 0,0 & 0 & 0,0 & 11 & 2,7 & 0,000 & 0,342 \\
\hline Baik & 16 & 4,1 & 62 & 15,4 & 308 & 77,0 & 3 & 0,8 & 399 & 97,3 & & \\
\hline $\begin{array}{l}\text { Konsumsi } \\
\text { suplemen gizi } \\
\text { sesuai anjuran } \\
\text { Belum baik }\end{array}$ & 4 & 1,0 & 11 & 2,6 & 2 & 0,5 & 0 & 0,0 & 17 & 4.3 & 0,000 & 0,329 \\
\hline Baik & 19 & 4,6 & 55 & 13,8 & 306 & 76,5 & 3 & 0,8 & 383 & 95,7 & & \\
\hline Status Kadarzi & & & & & & & & & & & & \\
\hline $\begin{array}{l}\text { Belum } \\
\text { Kadarzi }\end{array}$ & 22 & 5,5 & 59 & 14,7 & 103 & 25,7 & 1 & 0,3 & 185 & 46,2 & 0,000 & 0,465 \\
\hline Sudah Kadarzi & 1 & 0,3 & 7 & 1,8 & 205 & 51,3 & 2 & 0,6 & 215 & 53,8 & & \\
\hline
\end{tabular}

Hasil analisis statistik hubungan antara lima indikator kadarzi dan perilaku Kadarzi dengan status gizi Balita menurut indeks TB/U menunjukkan bahwa setiap indikator Kadarzi dan perilaku Kadarzi mempunyai hubungan yang signifikan dengan status gizi Balita menurut indeks $\mathrm{TB} / \mathrm{U}$ (nilai $\mathrm{p}=0,00$ ). Hasil uji korelasi spearman menunjukkan arah hubungan yang positif antara lima indikator Kadarzi dan perilaku Kadarzi dengan status gizi Balita menurut indeks TB/U. Hal tersebut berarti semakin baik perilaku Kadarzi, maka akan semakin baik status gizi Balita menurut indeks TB/U. Nilai korelasi paling besar terdapat pada indikator memberikan ASI eksklusif yaitu 0,543. Hal tersebut berarti perilaku memberikan ASI Eksklusif mempunyai pengaruh paling besar terhadap status gizi Balita menurut indeks TB/U. Gambaran status gizi Balita menurut indeks $\mathrm{TB} / \mathrm{U}$ berdasarkan lima indikator Kadarzi dan perilaku Kadarzi dijelaskan pada tabel 5.

\section{Pembahasan}

\section{Hubungan Penimbangan Berat Badan Secara Teratur dengan Status Gizi Balita}

Hasil uji chi square menunjukkan 
hubungan antara menimbang berat badan secara teratur dengan status gizi Balita mempunyai nilai $p<0,05$. Hal tersebut berarti ada hubungan yang signifikan antara perilaku menimbang berat badan secara teratur dengan status gizi Balita. Hasil uji korelasi spearman menunjukkan nilai korelasi positif antara menimbang berat badan secara teratur dengan status gizi Balita baik menurut indeks $\mathrm{BB} / \mathrm{U}$ maupaun TB/U. Nilai korelasi berharga positif menunjukkan bahwa menimbang berat badan secara teratur berdampak terhadap semakin membaiknya status gizi Balita.

Menimbang berat badan Balita secara teratur dilakukan responden dengan membawa Balita ke Posyandu setiap bulan. keluarga yang membawa Balitanya setiap bulan ke Posyandu akan meningkatkan pengetahuan keluarga. Peningkatan pengetahuan dalam hal kesehatan, tanda, dan gejala yang berhubungan dengan pertumbuhan Balita. Oleh karena itu keluarga tersebut akan segera melakukan tindakan untuk meminimalkan dampak yang lebih buruk lagi terhadap kondisi Balita. Hal tersebut sesuai dengan hasil penelitian Octaviani bahwa hubungan keaktifan keluarga dalam kegiatan di Posyandu dengan status gizi Balita menunjukkan hasil yang signifikan positif. ${ }^{6}$

Salah satu kegiatan Posyandu yaitu menimbang berat badan dan mengukur tinggi badan Balita. Kegiatan selanjutnya diikuti dengan pengisian Kartu Menuju Sehat (KMS) berdasarkan berat badan menurut umur. Hal tersebut berguna untuk mengetahui dengan segera bila terdapat kelainan atau ketidaksesuaian dengan grafik pertumbuhan pada KMS. Grafik pertumbuhan pada KMS menunjukkan perkembangan anak persatuan waktu. Kurva pertumbuhan dapat digunakan sebagai alat diagnostik guna tindakan preventif dan perbaikan. ${ }^{7}$

\section{Hubungan Pemberian ASI Eksklusif dengan Status Gizi Balita}

Hasil penelitian menunjukkan bahwa
Balita dengan status gizi baik lebih banyak terdapat pada keluarga yang memberikan ASI eksklusif dibandingkan dengan keluarga yang tidak memberikan ASI eksklusif. Sebaliknya Balita dengan status gizi buruk lebih banyak terdapat pada keluarga yang tidak memberikan ASI eksklusif. Balita dengan tinggi badan normal paling banyak terdapat pada keluarga yang memberikan ASI eksklusif. Hasil uji chi square menunjukkan hubungan yang signifikan antara perilaku memberikan ASI eksklusif dengan status gizi Balita. Hal tersebut sesuai dengan penelitian Kurnia (2013) yang menyatakan bahwa ada hubungan antara pemberian ASI eklsusif dengan status gizi Balita 6-24 bulan.

ASI merupakan makanan yang higienis, murah, mudah diberikan, dan sudah tersedia bagi bayi. ASI menjadi satusatunya makanan yang dibutuhkan bayi selama 6 bulan pertama hidupnya agar menjadi bayi yang sehat. Komposisinya yang dinamis dan sesuai dengan kebutuhan bayi menjadikan ASI sebagai asupan gizi yang optimal bagi bayi. ASI merupakan sumber gizi yang sangat ideal dengan komposisi seimbang dan disesuaikan dengan kebutuhan pertumbuhan bayi. ${ }^{8}$

Giri dalam penelitiannya menjelaskan bahwa pemberian ASI dapat mencegah malnutrisi pada anak. Teori tersebut menyebutkan bahwa terdapat korelasi positif antara pemberian ASI dengan status gizi anak. Semakin sering anak yang mendapat perhatian (lewat menyusui) mempunyai probabilitas yang lebih baik dibandingkan dengan bayi yang tidak disusui atau disusui tapi hanya sebentar saja. ASI mempunyai kelebihan yang meliputi 4 aspek, yaitu: gizi, kekebalan, ekonomi, dan kejiwaan. Aspek kejiwaan berupa jalinan kasih sayang yang penting untuk perkembangan mental dan kecerdasan anak. ${ }^{9}$

\section{Hubungan Konsumsi Makanan Beragam dengan Status Gizi Balita} Hasil penelitian menunjukkan bahwa 
kesadaran keluarga dalam menyediakan makanan beragam pada Balita sudah mencapai 80,3\%. Sebagian kecil Balita pada penelitian ini masih mempunyai pola makan yang kurang beragam (19,7\%). Keragaman makanan dilihat dari pola makanan yang memenuhi gizi seimbang. Gizi seimbang mengandung unsur zat tenaga (makanan pokok), zat pembangun dan pemelihara jaringan (lauk pauk), dan zat pengatur (sayuran dan atau buahbuahan). Balita yang mengonsumsi makanan beragam cenderung memiliki status gizi baik ${ }^{10}$. Hal tersebut diperkuat dengan penelitian Qonitun yang menunjukkan bahwa ada hubungan yang positif antara jenis dan frekuensi makan dengan status gizi Balita. ${ }^{11}$

Salah satu penyebab masih tingginya masalah gizi kurang pada Balita adalah karena kualitas makanan. Sebagian besar masyarakat Indonesia terutama pada Balita masih belum mengonsumsi makanan dengan gizi seimbang. Asupan makanan yang kurang beragam secara terus menerus beresiko mengalami kurang gizi. Keragaman jenis makanan yang dikonsumsi oleh Balita umur 24-59 bulan sangat menentukan sumbangan atau kontribusi zat-zat gizi dalam pemenuhan kebutuhan gizi anak. Hasil penelitian Aditianti menunjukkan bahwa konsumsi makanan pada anak usia 24-59 bulan dengan tinggi badan normal lebih beragam dibandingkan dengan anak stunting. ${ }^{12}$

Hasil penelitian juga menunjukkan pada keluarga yang sudah mengonsumsi makanan beragam masih ditemukan Balita dengan status gizi lebih sebanyak satu orang. Hal tersebut karena penyelesaian masalah status gizi tidak hanya dilakukan dengan memberikan makanan yang beragam saja tetapi jumlahnya harus sesuai dengan kebutuhan. Pemenuhan kebutuhan nutrisi yang berlebihan dapat menimbulkan terjadinya obesitas. ${ }^{13}$

Tidak ada satu pun jenis makanan yang mengandung semua zat gizi secara lengkap. Setiap jenis bahan makanan mengandung jenis dan jumlah zat gizi yang tidak sama sehingga saling memiliki kekurangan dan kelebihan. Makanan yang beragam menggunakan berbagai jenis bahan makanan yang dapat memberikan manfaat yang besar bagi kesehatan. Hal tersebut disebabkan karena kelebihan kandungan zat gizi tertentu pada bahan makanan tertentu akan melengkapi kekurangan zat gizi yang sama dari bahan makanan lainnya. ${ }^{13}$

Suatu makanan dikatakan beragam bila dalam suatu hidangan makanan terdiri dari unsur zat penghasil energi, zat pembangun dan zat pengatur. Makanan sumber energi dalam hidangan sehari-hari berasal dari makanan pokok seperti nasi, mie, jagung, umbi-umbian, sagu, dan roti. Makanan sumber zat pembangun dan pemelihara jaringan berasal dari lauk-pauk. Lauk-pauk meliputi lauk hewani seperti ikan, daging, telur, unggas, dan susu. Lauk nabati meliputi tahu, tempe, dan kacangkacangan. ${ }^{14}$

\section{Hubungan Penggunaan Garam Beryodium dengan Status Gizi Balita}

Hasil uji chi square menunjukkan ada hubungan yang signifikan antara penggunaan garam beryodium dengan status gizi Balita baik menurut indeks $\mathrm{BB} / \mathrm{U}$ maupun indeks $\mathrm{TB} / \mathrm{U}$ dengan nilai $\mathrm{p}<0,05$. Balita berstatus gizi baik pada keluarga yang menggunakan garam beryodium sebesar $80,8 \%$, sedangkan pada keluarga yang tidak menggunakan garam beryodium persentasenya hanya $0,7 \%$. Kondisi tersebut menunjukkan bahwa penggunaan garam beryodium memengaruhi status gizi Balita. Hasil penelitian tersebut diperkuat oleh hasil penelitian Chairunisa yang menunjukkan bahwa penggunaan garam beryodium berpengaruh terhadap status gizi Balita. ${ }^{15}$

Garam beryodium adalah garam yang telah diperkaya dengan yodium. Yodium dibutuhkan tubuh untuk membuat hormon yang mengatur pertumbuhan dan perkembangan kecerdasan. Penggunaan garam beryodium dimaksudkan untuk memenuhi kebutuhan yodium setiap 
anggota rumah tangga, terutama anak yang masih dalam proses pertumbuhan. Djokomoeldjanto dalam Chairunnisa mengatakan bahwa yodium adalah jenis elemen mineral mikro kedua sesudah zat besi yang dianggap penting bagi kesehatan. Yodium dalam tubuh diperlukan untuk produksi hormon tiroksin. Tiroksin sangat penting untuk pertumbuhan fisik, perkembangan motorik dan mental anak. Kadar hormon tiroid dalam aliran darah yang rendah disebabkan oleh kekurangan yodium dapat menyebabkan penghambatan pertumbuhan serta perkembangan manusia. Perilaku ibu dalam memilih garam akan menentukan konsumsi yodium pada rumah tangga. Tingkat konsumsi yodium ini pada akhirnya akan berpengaruh terhadap status penggunaan yodium. Penggunaan garam beryodium di rumah tangga mempunyai manfaat yang penting untuk mencegah penyakit gondok. ${ }^{15}$

\section{Hubungan Konsumsi Suplemen Gizi Sesuai Anjuran dengan Status Gizi Balita}

Hasil uji chi square menunjukkan ada hubungan yang signifikan antara konsumsi kapsul vitamin A dengan status gizi Balita. Hal tersebut dinyatakan dengan nilai $\mathrm{P}=0,000$. Depkes RI (2007) menjelaskan bahwa kekurangan vitamin A merupakan salah satu masalah gizi yang dihadapi pada anak usia Balita. Indonesia dinyatakan bebas dari xeropthalmia sejak tahun 1992. Di Indonesia terdapat Balita yang mempunyai serum retinol $<20$ $\mathrm{mcg} / 100 \mathrm{ml}$ sebanyak 50\%. Rendahnya serum retinol pada Balita menyebabkan Balita beresiko tinggi terkena xeropthalmia dan menurunnya tingkat kekebalan tubuh. Hal tersebut menyebabkan Balita mudah terserang penyakit infeksi. ${ }^{16}$

Fungsi Vitamin A secara umum yaitu: membantu pembentukan jaringan tubuh dan tulang; meningkatkan penglihatan dan ketajaman mata; memelihara kesehatan kulit dan rambut; meningkatkan kekebalan tubuh; memproteksi jantung; anti kanker dan katarak; serta mendukung pertumbuhan dan reproduksi. Anak-anak yang cukup mendapat vitamin A bila terkena diare, campak atau penyakit infeksi lain, maka penyakit-penyakit tersebut tidak mudah membahayakan jiwa anak. ${ }^{14}$

Defisiensi vitamin A pada Balita mengakibatkan terjadinya hambatan pertumbuhan. Vitamin A dibutuhkan untuk perkembangan tulang dan sel epitel yang membentuk email gigi. Orang yang kekurangan vitamin A beresiko pertumbuhan tulang terhambat dan bentuk tulang tidak normal. Vitamin A berpengaruh terhadap fungsi kekebalan tubuh manusia dan hewan. Sistem kekebalan membantu mencegah atau melawan infeksi. Tubuh membuat sel darah putih yang dapat menghancurkan berbagai bakteri dan virus berbahaya. ${ }^{14}$

\section{Kesimpulan}

Perilaku keluarga sadar gizi berpengaruh terhadap status gizi Balita di Kelurahan Cimahpar Kota Bogor. Ada pengaruh yang signifikan antara perilaku keluarga sadar gizi terhadap status gizi Balita baik menurut indeks BB/U maupun TB/U $(p<0,05)$. Lima Indikator Kadarzi yaitu: menimbang berat badan secara teratur; memberikan ASI eksklusif; mengonsumsi makanan beragam; menggunakan garam beryodium; dan mengonsumsi suplemen gizi sesuai anjuran. Lima indikator tersebut masingmasing menunjukkan hubungan yang signifikan terhadap status gizi Balita. Hasil uji korelasi spearman menunjukkan konsumsi makanan beragam paling berpengaruh terhadap status gizi Balita menurut indeks $\mathrm{BB} / \mathrm{U}$. Indikator Kadarzi yang paling berpengaruh terhadap status gizi Balita menurut indeks TB/U adalah memberikan ASI eksklusif.

\section{Saran}

Meningkatkan motivasi ibu memberikan ASI eksklusif dengan memberikan hadiah dan sertifikat bagi bayi yang lulus ASI eksklusif sampai usia 6 
bulan.

\section{Daftar Pustaka}

1. Departemen Kesehatan RI. Buku pedoman keluarga sadar gizi. Jakarta; 2010.

2. Kementerian Kesehatan RI. Rencana Pembangunan Menengah Nasional (RPJMN) 2015-2019. Jakarta; 2015.

3. Kementerian Kesehatan RI. Riset kesehatan dasar (Riskesdas) tahun 2013. Jakarta; 2013.

4. Dinas Kesehatan Kota Bogor. Evaluasi Program Gizi Tahun 2015. Bogor; 2016.

5. Puskesmas Bogor Utara. Profile Gizi Puskesmas Bogor Utara tahun 2015. Bogor; 2016.

6. Octaviani U, Juniarti N, Mardiyah A. Hubungan keaktifan keluarga dalam kegiatan posyandu dengan status gizi Balita di desa Rancaekek Kulon Kecamatan Rancaekek. Bandung: Fakultas Ilmu Keperawatan Universitas Padjadjaran Bandung. 2011; Vol.1. No. 2.

7. Kementerian Kesehatan RI. Strategi penimbangan Balita di posyandu. Jakarta; 2014.

8. Dinas Kesehatan Kota Bogor. Inisiasi menyusu dini dan ASI eksklusif. Bogor; 2011.

9. Giri WAM, Muliarta IW, Sri Wahyuni N. Hubungan pemberian ASI eksklusif terhadap status gizi Balita usia 6-24 bulan di kampung Kajanan Buleleng. Bali; Sarjana strata 1
Fakultas Olahraga dan Kesehatan Universitas Pendidikan Ganesha Bali.2013; Vol.2 No.1.

10. Djaeni A. Ilmu Gizi. Jakarta: PT Dian Rakyat; 2012.

11. Qonitun U. Hubungan antara jenis dan frekuensi makan dengan status gizi anak usia 36-48 bulan (studi 5 posyandu di Desa Remen Kecamatan Jenu Kabupaten Tuban). Tuban: Stikkes Tuban. 2015; Vol 2. No.1.

12. Aditianti, Prihatini S, Hermina. Pengetahuan, sikap, dan perilaku individu tentang makanan beraneka ragam sebagai salah satu indikator keluarga sadar gizi. Jakarta; Puslitbang upaya kesehatan masyarakat Jakarta. 2015; Vol.44. No.2.

13. Kementerian Kesehatan RI. Pedoman Gizi Seimbang (PGS). Jakarta; 2014

14. Sediaoetama. Ilmu Gizi. Jakarta: Dian Rakyat; 2010.

15. Chairunnisa. Pengaruh penggunaan garam beryodium terhadap status gizi Balita pendek di kecamatan Amuntai Tengah Kabupaten Hulu Sungai Utara Tahun 2011. Skripsi. Banjar Baru: Program studi S1 Gizi Stikes Husada Borneo Banjar Baru; 2011. h. 7-8

16. Jannah R. Pengaruh pemberian suplemen vitamin terhadap perubahan status gizi $(\mathrm{BB} / \mathrm{U})$ Balita Bawah Garis Merah (BGM) di wilayah kerja Puskesmas Kambat Utara Kabupaten Hulu Singai Tengah (HST). Skripsi. Banjar Baru: Program Studi S1 Gizi Stikes Husada Borneo Banjar Baru; 2011. h. 18-22 